\title{
JUROS: O PREÇO DO DINHEIRO
}

\author{
Eli Eustáquio de Oliveira \\ Mestrando - Mestrado Profissional em Administração - MPA (Finanças); \\ Prof. do Curso de Ciências Contábeis da Faculdade de Ciências Humanas de Pedro Leopoldo.
}

A complexidade crescente dos problemas econômico-financeiros nas empresas, face às exigências do mercado, tem ocasionado a necessidade de aplicação de técnicas de planejamento e controle dos resultados, hoje em dia, fundamentais para a efetiva prática administrativa dos negócios.

O objetivo de uma empresa, na geração de bons resultados, se a curto ou longo prazo, em uma economia de livre mercado e em regime de concorrência, está intimamente ligado à maximização de sua rentabilidade. Dessa forma, o êxito ou o fracasso de uma empresa são mensurados, em grande parte, através de seu lucro. Manter custos em valores inferiores às receitas é um problema aflitivo, o que aumenta a complexidade à medida em que se ampliam as operações da empresa.

Nesta perspectiva, a questão das taxas de juros, hoje, constitui um ponto importante, principalmente para o pequeno e médio empresário, que nem sempre dispõe de uma assessoria.

Com o arrocho creditício, o custo do dinheiro pode inviabilizar a empresa se não houver planejamento prévio da necessidade de aplicação do capital, principalmente oriundo da contratação de financiamentos ou empréstimos através do sistema bancário.

Nos tempos atuais, recorrer à capitação de recursos no mercado financeiro é uma tarefa complexa e difícil, não só pela inabilidade de atender às exigências impostas pelo sistema financeiro (garantias, valor patrimonial, grau de risco, etc). como também, pelo elevado custo do dinheiro ao qual se somam outros encargos, elevando as taxas reais a patamares insuportáveis. Todos esses fatores colocam em risco o patrimônio da empresa, fato que, às vezes, passa desapercebido ao empresário, tendo em vista a sua ansiedade em manter negócios em marcha.

Considerando, por exemplo, um empréstimo contratado à taxa de $3 \%$ ao mês, somando-se o IOF (Imposto sobre Operações financeiras), a CPMF (Contribuição Provisória sobre Movimentação Financeira) e outros custos de financiamento, a taxa real acaba por ser extremamente nociva à saúde financeira da empresa.

Se, para financiar o ativo fixo ou para manter o capital de giro houver uma excessiva dependência da empresa junto ao mercado financeiro, o empresário poderá se ver diante de uma situação angustiante em virtude do já conhecido efeito "bola de neve".

Atualmente, observa-se, também, que a recessão, oriunda das incertezas e turbulências do mercado face às mazelas e crise do mercado acionário internacional, tem provocado reflexo nas empresas, com queda e desequilíbrio da rentabilidade, afetando a relação lucro/patrimônio líquido.

Nesta ótica, é muito importante, para o empresário, conhecer e discutir em que base está sendo negociada uma operação, tanto de investimento como de financiamento. Não poderá ficar iludido com as taxas oferecidas pelos investidores, nem se esquecer do retorno do capital aplicado em função do prazo de contratação de uma operação de venda à prazo. Torna-se importante ressaltar que um financiamento oferecido à taxa linear de $5 \%$ ao mês significa $60 \%$ ao ano e que uma taxa real mensal de $5 \%$ irá representar $80 \%$ ao ano. 
Inegavelmente, os cálculos se complicam à medida que se queira incorporar outras variáveis praticadas pelo mercado financeiro. No entanto, o nosso objetivo, nesse momento, não é o de discutir a melhor regra matemática, mas sim, apenas o de alertar o empresariado para estar atento ao preço que se paga pelo dinheiro quando da efetivação de qualquer operação de crédito (compra, venda, financiamento, investimento, etc) a fim de que se possa evitar a inadimplência da empresa e o comprometimento da sua base de sustentação, que é o patrimônio. 